\title{
PLASMA OESTRADIOL, LUTEINIZING HORMONE AND PROGESTERONE DURING PREGNANCY IN THE BEAGLE BITCH
}

\author{
GWYNETH E. JONES,* A. R. BOYNS, ${ }^{*}$ E. H. D. GAMERON,* \\ E. T. BELL, $\ddagger$ D. W. CHRISTIE $\ddagger$ AND M. F. PARKES $\ddagger$ \\ * Tenovus Institute for Cancer Research, and \\ $\dagger$ Department of Chemical Pathology, Welsh National School of Medicine, Heath, Cardiff, \\ Wales, and $\ddagger$ Pedigree Petfoods Limited, Melton Mowbray, Leicestershire
}

(Received 24th May 1973)

Recent reports have recorded results of the simultaneous measurement of the concentration of progesterone and LH in the blood plasma of the dog during the oestrous cycle and pregnancy (Jones, Boyns, Bell, Christie \& Parkes, 1973) and of oestradiol-17 $\beta$, progesterone and LH during the oestrous cycle (Jones, Boyns, Cameron, Bell, Christie \& Parkes, 1973). We report here the results of simultaneous measurement of oestradiol-17 $\beta$, progesterone and LH in the plasma of the Beagle bitch during pregnancy.

Four Beagle bitches were maintained under controlled conditions and blood samples were collected between 14.00 and 15.00 hours; all animals were parous. The onsets of pro-oestrus and oestrus were determined by methods previously described (Christie \& Bell, 1971). The bitches were each mated on two occasions during the first week of oestrus and had apparently normal pregnancies.

Progesterone was determined by a protein-binding method (Christie, Bell, Horth \& Palmer, 1971). Canine LH and oestradiol-17 $\beta$ were measured by specific radioimmunoassays (Boyns, Jones, Bell, Christie \& Parkes, 1972; Cameron \& Jones, 1972).

Because of the differences in length of pro-oestrus and oestrus in individual animals, the duration of these phases in pregnant bitches was taken as $100 \%$. Data for progesterone, LH and oestradiol-17 $\beta$ were allocated to appropriate positions on the transformed time scale. Thus, if pro-oestrus lasted for 5 days, the values for Days 2 and 4 would be allocated to $40 \%$ and $80 \%$ on the transformed scale. The data for the four bitches over a series of time intervals were then pooled, giving approximately equal group sizes for statistical analysis.

The mean concentration of progesterone was low during pro-oestrus. Levels then rose rapidly to a maximum during the first half of pregnancy before falling towards term. In individual animals, $\mathrm{LH}$ concentrations were highest during early oestrus and subsequently decreased to low levels that persisted throughout pregnancy.

The mean level of oestradiol-17 $\beta$ during pro-oestrus was $11.9 \pm 1.4 \mathrm{pg} / \mathrm{ml}$ (mean \pm S.E.M.). Plasma concentrations reached a maximum $(17 \cdot 2 \pm 3.8 \mathrm{pg} / \mathrm{ml})$ in the first half of oestrus and fell away during the second half of oestrus to a 
minimum $(9 \cdot 2 \pm 1 \cdot 2 \mathrm{pg} / \mathrm{ml}$ ) in early pregnancy (Days 1 to 6$)$. Levels then rose and remained fairly steady at $13.8 \pm 0.7 \mathrm{pg} / \mathrm{ml}$ until Day 50 before declining once again between Days 51 and 60 to a concentration of $7 \cdot 7 \pm 1.0 \mathrm{pg} / \mathrm{ml}$ (Text-fig. 1).

In most species, the duration of pregnancy is considerably longer than the oestrous interval of the non-pregnant animal. In the dog, the duration of pregnancy (63 days) is approximately equal to that of metoestrus (Christie \& Bell, 1971). It is not altogether surprising, therefore, that the patterns of LH

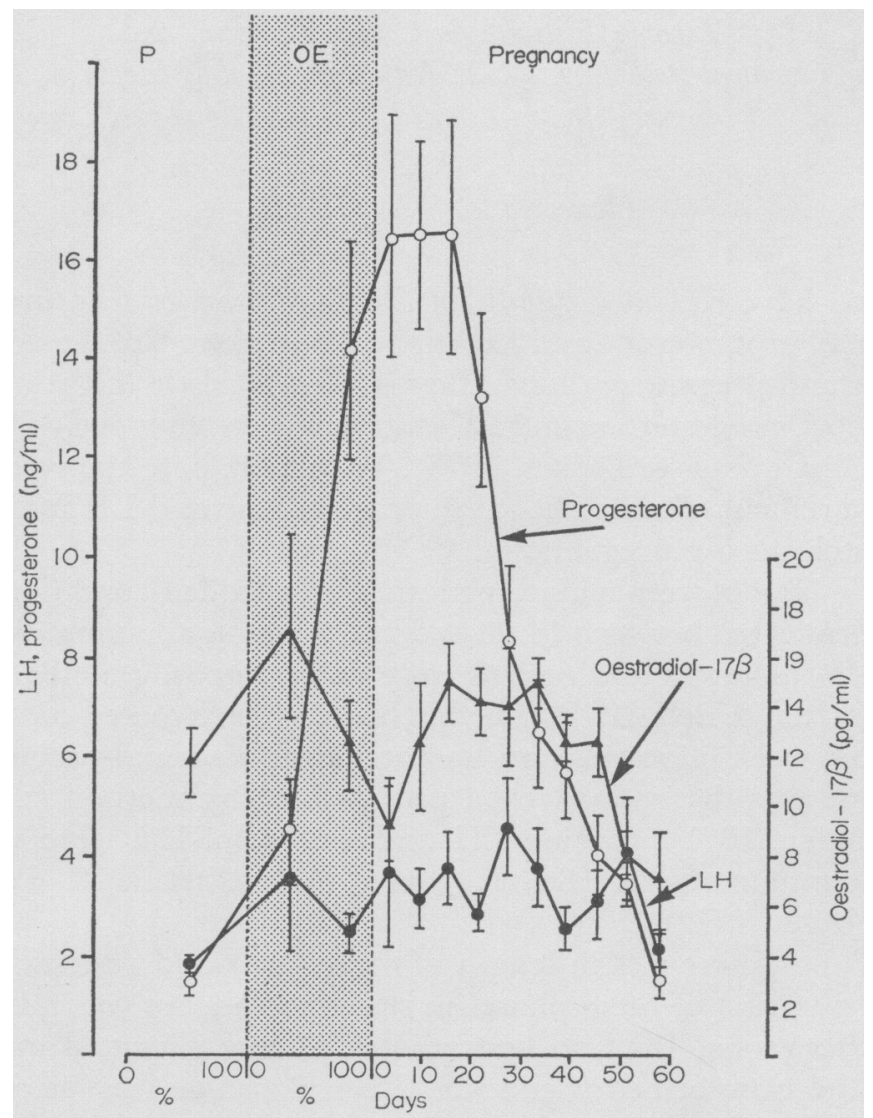

TexT-FIG. 1. Oestradiol-17 $\beta$, progesterone and LH in the blood plasma of four Beagle bitches during pregnancy. The points and vertical lines represent means \pm S.E.M. $\mathbf{P}=$ pro-oestrus; $\mathrm{OE}=$ oestrus.

and progesterone secretion in the pregnant and the non-pregnant Beagle bitch are similar (Jones, Boyns, Bell, Christie \& Parkes, 1973; Jones, Boyns, Cameron, Bell, Christie \& Parkes, 1973).

Plasma concentrations of oestradiol-17 $\beta$ in the bitch reach a maximum during early oestrus and then fall to significantly lower levels during metoestrus (Jones, Boyns, Cameron, Bell, Christie \& Parkes, 1973). The studies reported here indicate that the levels of oestradiol-17 $\beta$ found in pregnancy are close to those of 
early oestrus. This suggests that plasma concentrations of this hormone in pregnancy are somewhat greater than those of the non-pregnant animal during metoestrus. Other workers have stated that a peak in plasma oestradiol-17 $\beta$ concentration occurs during the first 4 weeks of pregnancy in the bitch (Metzler, Eleftheriou \& Fox, 1966). The significance of these observations is doubtful because the reported concentrations of the hormone in the plasma were approximately 10,000 times greater than have been found in the non-pregnant animal (Bell, Christie \& YoungLai, 1971; Jones, Boyns, Cameron, Bell, Christie \& Parkes, 1973). The findings of Kristofferson \& Velle (1960) are also relevant in this respect. They were unable to detect oestradiol-17 $\beta$ in the urine of the pregnant bitch and concluded that urinary concentrations of the hormone were probably less than $1 \mathrm{ng} / \mathrm{ml}$.

Plasma oestrogen concentrations in the cow (Henricks, Dickey, Hill \& Johnston, 1972), in the ewe (Challis, 1971) and in the human female (Loriaux, Ruder, Knab \& Lipsett, 1972) show a marked rise during pregnancy, particularly towards term. The dog appears to be unusual in that the magnitude of the increase in plasma oestrogen is much less than that observed in these species and that a distinct increase does not occur before parturition.

We thank the Tenovus Organisation for generous financial support.

\section{REFERENCES}

Bell E. T., Christie, D. W. \& Younglai, E. V. (1971) Plasma oestrogen levels during the canine oestrous cycle. F. Endocr. 51, 225.

Boyns, A. R., Jones, G. E., Bell, E. T., Christie, D. W. \& Parkes, M. F. (1972) Development of a radioimmunoassay for canine luteinizing hormone. F. Endocr. 55, 279.

Cameron, E. H. D. \& Jones, D. (1972) Some observations on the measurement of oestradiol-17 $\beta$ in human plasma by radioimmunoassay. Steroids, 20, 737.

Challis, J. R. G. (1971) Sharp increase in free circulating oestrogens immediately before parturition in sheep. Nature, Lond. 229, 208.

Christie, D. W. \& Bell, E. T. (1971) Endocrinology of the oestrous cycle in the bitch. F. small Anim. Pract. 12, 383.

Christie, D. W., Bell, E. T., Horth, C. \& Palmer, R. F. (1971) Peripheral plasma progesterone levels during the canine oestrous cycle. Acta endocr., Copenh. 68, 543.

Henricks, D. M., Dickey, J. F., Hill, J. R. \& Johnston, W. E. (1972) Plasma estrogen and progesterone levels after mating and during late pregnancy and postpartum in cows. Endocrinology, 90, 1336.

Jones, G. E., Boyns, A. R., Belt, E. T., Christie, D. W. \& Parkes, M. F. (1973) Immunoreactive luteinizing hormone and progesterone during pregnancy and following gonadotrophin administration in Beagle bitches. Acta endocr., Copenh. 72, 573.

Jones, G. E., Boyns, A. R., Cameron, E. H. D., Bell, E. T., Christie, D. W. \& Parkes, M. F. (1973) Plasma oestradiol, luteinizing hormone and progesterone during the oestrous cycle in the Beagle bitch. F. Endocr. 57, 331.

Kristopferson, J. \& VelLe, W. (1960) Urinary oestrogens of the dog. Nature, Lond. 185, 253.

Loriaux, D. L., Ruder, H. J., KNAB, D. R. \& LipsetT, M. B. (1972) Estrone sulfate, estrone, estradiol and estriol levels in human pregnancy. F. clin. Endocr. Metab. 35, 887.

Metzler, F., Eleftheriov, B. E. \& Fox, M. (1966) Free estrogens in dog plasma during the estrous cycle and pregnancy. Proc. Soc. exp. Biol. Med. 121, 374. 